\title{
BIOGENIC SYNTHESIS SILVER NANOPARTICLES USING PELTOPHORUM PTEROCARPUM LEAF EXTRACTS AND ITS ANTIMICROBIAL EFFICACY AGAINST SELECTIVE PATHOGENS
}

\section{P. ANNAMALAI, P. BALASHANMUGAM, P. T. KALAICHELVAN}

Centre for Advanced Studies in Botany, University of Madras, Chennai 600025, India

Email: annaias1960@gmail.com

Received: 17 Jul 2018, Revised and Accepted: 04 Sep 2018

\section{ABSTRACT}

Objective: The present study was aimed to screen silver nanoparticles (AgNPs) using different plant extracts and also to study their antimicrobial property against different human pathogens.

Methods: Nine different plants, namely Parthenium hispidum, Vinga rose, Catheranthus roseus, Phyllanthus amarus, Azadirachta indica, Jatropa curcas, Tectona grandis, Ocimum sanctum, and Peltophorum pterocarpum were screened for the synthesis of AgNPs. The AgNPs were synthesized using leaf extracts and was well characterized using a UV-Visible spectrophotometer, transmission electron microscopy (TEM), energy dispersive Xray spectroscopy (EDX), X-ray diffraction (XRD) and zeta potential measurement. The AgNPs was tested for their antibacterial and antifungal efficacy using agar well diffusion method.

Results: Among the nine different plant extracts screened, AgNPs synthesized using Peltophorum pterocarpum leaf extract showed good stability even after one month with maximum absorption spectra of $425 \mathrm{~nm}$. The synthesized AgNPs was found to be spherical in shape with an average size ranging from 20 to $60 \mathrm{~nm}$. The EDX spectrum reveals the presence of silver peaks and the XRD spectrum confirms the crystalline nature of AgNPs. A Maximum zone of inhibition of $18.04 \pm 0.74$ was found when the synthesized AgNPs was tested against B. subtilis, and $12.34 \pm 0.31$ against A. niger when the concentration was AgNPs was maintained at $100 \mu \mathrm{g} / \mathrm{ml}$.

Conclusion: The results of the present study conclude that the AgNPs synthesized using Peltophorum pterocarpum leaf extracts is found to be stable and possesses broad-spectrum antibacterial activity against different tested pathogens.

Keywords: Antibacterial, Antifungal, Plant extracts, Silver nanoparticles

(C) 2018 The Authors. Published by Innovare Academic Sciences Pvt Ltd. This is an open-access article under the CC BY license (http://creativecommons.org/licenses/by/4.0/) DOI: http://dx.doi.org/10.22159/ijap.2018v10i6.28573

\section{INTRODUCTION}

The field nanoscience deals with the study of fabricating nanostructures between the diameters of 1 to $100 \mathrm{~nm}$ which can be used in different areas of science including medicine, biology, materials science, and chemistry etc. Recently, the field of nanotechnology has started emerging one of the most promising areas of science with diverse potential applications. Among the different nanostructures, the application of metal nanoparticles, especially silver and silver associated nanostructures has created a major impact in the field of biomedicine. The silver nanoparticles (AgNPs) are found to be very attractive due to its antimicrobial, angiogenic and anticancer properties $[1,2]$. Due to a wide range of biological applications of AgNPs, there is huge interest in developing a novel protocol using various biological sources to synthesize nanoparticles with different size and shapes [3]. Traditionally nanoparticles were synthesized using the physical and chemical process where it included the utilization of various chemicals which could be hazardous to both biological systems and environment [4]. Comparing with the existing physical and chemical methods, the biologically mediated nanoparticles synthesis process was found to be less toxic, safe and eco-friendly [5].

The utilization of plant and plant-based components for the treatment and prevention of various health-related complications have been in practice for many decades. Several bioactive components were used for the treatments which found to be similar to various chemical compounds $[6,7]$. In the plant-mediated synthesis of metal nanoparticles, various active molecules of plants such as flavonoids, terpenoids, amines, tannins, ketone, and proteins were used as reducing and capping agents $[8,9]$. Several researchers have studied the green biosynthesis of AgNPs using different plants, including Pulicaria glutinosa [10], Plumbago zeylanica [11], Albizia adianthifolia [12], Achillea biebersteinii [1], Origanum vulgar [13], Annona squamosa [14] and Erythrina indica [15].

Recently, the development of drug-resistant pathogens has created a major impact globally, and demands for the production of novel compounds with potent antimicrobial property have been increased [16]. Currently, the AgNPs have been thoroughly investigated extensively for its antimicrobial potential due to its strong bactericidal and inhibitory properties against several pathogenic strains [17-19]. Silver in the form of AgNPs tends to have increased surface area, resulting in an enhanced antimicrobial property. Though AgNPs has been extensively used in many areas, the mechanism of the antibacterial is still unclear. Studies have hypothesized that AgNPs may cause cell lysis by interacting with a thiol group, thus inactivating enzymes $[20,21]$.

Globally, the development of multidrug-resistant pathogens has created a serious issue which has a profound impact on public health. This is mainly due to the extreme and improper use of antibiotics, thus, leads to the development of antibiotic-resistant genes which may transfer from between the bacteria in higher level organisms. The metallic nanoparticles such as AgNPs can be replaced in future as an alternate substitute due to its broadspectrum antimicrobial property. In this view, the present study aims to explore the different plants for the synthesis of AgNPs using plant extracts as reducing agent and to study the efficacy of synthesized silver nanoparticles as a potent source of the antimicrobial agent against several bacterial pathogens.

\section{MATERIALS AND METHODS}

\section{Preparation of the plant extract}

The mature leaves of the following plants Parthenium hispidum, Vinga rose, Catheranthus roseus, Phyllanthus amarus, Azadirachta indica, Jatropa curcas, Tectona grandis, Ocimum sanctum, and Peltophorum pterocarpum were locally collected from the Centre for advanced studies in Botany, University of Madras, Chennai (Latitude $13.010^{\circ}$ and Longitude $80.239^{\circ}$ ). Identification of plant materials was done at the Centre for Advanced studies in Botany and voucher specimens of all plants where serially numbered as given: Parthenium hispidum (KA1), Vinga rose (KA2), Catheranthus 
roseus (KA3), Phyllanthus amarus (KA4), Azadirachta indica (KA5), Jatropa curcas (KA6), Tectona grandis (KA7), Ocimum sanctum (KA8) and Peltophorum pterocarpum (KA9). The leaves of the different plants were brought to the laboratory, thoroughly washed with distilled water, made into small pieces and kept in shadow drying. The dried leaves were made into powder using a mixer grinder and stored in the airtight container until further use. Ten gram of leaf powder of each plant were mixed in $100 \mathrm{ml}$ of distilled water and kept in a rotary shaker incubator for $48 \mathrm{~h}$. After incubation, the extracts of each plant were collected by passing it through Whatman's No.1 filter paper, and the filtrate was stored at $4{ }^{\circ} \mathrm{C}$ for further analysis.

\section{Screening of plant extracts for AgNPs synthesis}

In the present study, the leaf extracts of different plants were screened for the synthesis of AgNPs. To one ml of different leaf extracts, $9.0 \mathrm{ml}$ of $1 \mathrm{mmol}$ silver nitrate was mixed separately, and the tubes were incubated in dark conditions at room temperature for $24 \mathrm{~h}$. The solution containing plant extracts and silver nitrate was monitored for colour change, precipitation and agglomeration of nanoparticles [22]. During the preliminary investigation, among the different plant extracts tested, the AgNPs synthesized using Peltophorum pterocarpum leaf extracts showed good stability and hence it was utilized for further studies.

\section{Characterization of synthesized AgNPs}

\section{UV-Visible spectroscopy}

The AgNPs synthesized using Peltophorum pterocarpum leaf extracts were characterized using the UV-Visible spectrophotometer. The freshly synthesized AgNPs using plant extracts was analyzed for their maximum absorption spectra using UV-Visible spectrophotometer (U 2900, Hitachi) in the range of 300 to $700 \mathrm{~nm}$ [22].

\section{Stability studies of AgNPs}

The AgNPs synthesized using Peltophorum pterocarpum was investigated for their stability by analyzing the UV-Vis spectra, precipitation and agglomeration property. The synthesized AgNPs was regularly monitored for the maximum absorption spectra from $0 \mathrm{~h}$ to 1 mo using UV-Vis spectrophotometer and in addition, was also monitored for precipitation and agglomeration of AgNPs.

\section{X-ray diffraction (XRD)}

The AgNPs synthesized was subjected to XRD studies in order to study the crystalline nature of AgNPs. For this analysis, the AgNPs was dried; coated on XRD grid and the XRD spectrum was recorded at a voltage of $40 \mathrm{kV}$ with $\mathrm{Cu}-\mathrm{Ka}$ radiations using Philips X-ray diffractometer [23].

\section{Fourier transform infrared (FTIR) spectroscopy}

The FTIR study was performed to determine the different functional groups associated with the synthesized AgNPs. For FTIR measurement, the phytogenic AgNPs was dried and mixed with potassium bromide to form a pellet. The pellet was then analyzed for FTIR spectra in the range of 4000 to $400 \mathrm{~cm}^{-1}$ using FTIR spectroscopy.

\section{Transmission electron microscopy (TEM)}

The TEM analysis was performed to determine the size of the synthesized AgNPs. The AgNPs synthesized using plant extract was diluted with sterile distilled water; applied to carbon-coated copper TEM grids and allowed to dry under room temperature [24]. The grids were then analyzed using a TEM microscope (FEI Tecnai) at $100 \mathrm{kV}$ coupled with energy dispersive X-ray spectroscopy (EDX) and also selected area electron diffraction (SAED).

\section{Antibacterial property of AgNPs}

Four different bacterial strains, namely two Gram-positive bacteria, Staphylococcus aureus (MTCC-96), Bacillus subtilis (MTCC-441) and two Gram-negative bacteria such as Escherichia coli (MTCC-443),
Pseudomonas aeruginosa (MTCC-1688), were procured from the Institute of Microbial Technology, Chandigarh, India and were used for antibacterial efficacy of synthesized AgNPs.

The antibacterial activity of phytogenic AgNPs was evaluated using a modified agar well diffusion method. Briefly, under aseptic conditions, sterile mueller hinton agar (MHA) was prepared in sterile Petri plates. Freshly prepared overnight bacterial test strains from mueller hinton broth were inoculated on sterile mueller hinton agar plates using lawn culture method.

The media plates were then punched with five different wells of 4 $\mathrm{mm}$ diameter using a sterile punch borer. Each well was loaded with varying concentrations of synthesized AgNPs $(25,50,75,100 / \mathrm{ml})$ and positive control, gentamicin $(10 \mu \mathrm{g} / \mathrm{ml})$. Finally, the petri plates loaded with AgNPs were incubated at $37^{\circ} \mathrm{C}$ for $24 \mathrm{~h}$. At the end of incubation, the diameter of the inhibition zone was measured for each test strain and was recorded [25].

\section{Antifungal activity of AgNPs}

The AgNPs synthesized using Peltophorum pterocarpum leaf extract was tested for their antifungal activity against human fungal pathogens. Modified agar well diffusion method was used to determine the antifungal activity of AgNPs against Aspergillus niger [26]. Briefly, fungal spores of 1 x $10^{6}$ spores $/ \mathrm{ml}$ were inoculated on sterile potato dextrose agar plate using the spread plate technique. Five wells of $4 \mathrm{~mm}$ diameter were made using sterile punch borer and varying concentration of synthesized AgNPs $(25,50,75$, $100 / \mathrm{ml})$ and positive control, amphotericin B $(10 \mu \mathrm{g} / \mathrm{ml})$. The plates were then incubated at $27^{\circ} \mathrm{C}$ for 3 to $4 \mathrm{~d}$, and the zone of inhibition was measured.

\section{Statistical analysis}

In the present study, the experiments were performed independently for three times. The obtained values were processed and calculated using GraphPad Prism 6.0 (GraphPad Software, Inc.; USA) software.

\section{RESULTS AND DISCUSSION}

In the present study, nine different plant leaves extracts namely, Parthenium hispidum, Vinga rose, Catheranthus roseus, Phyllanthus amarus, Azadirachta indica, Jatropa curcas, Tectona grandis, Ocimum sanctum, and Peltophorum pterocarpum were tested for the biogenic synthesis of AgNPs. All the five different plant extracts supported the synthesis of AgNPs within $24 \mathrm{~h}$ by a visible change in the colouration from pale yellow to brown.

However, AgNPs synthesized using Peltophorum pterocarpum leaves extract showed much more stable when compared with AgNPs synthesized using other plant extracts (fig. 1). Okafor and co-workers investigated the synthesis of AgNPs using reducing agents from aqueous plant extracts from seven different plant leaves [27]. The colour change was due to the presence of various plant components such as alkaloids, saponins, flavonoids, steroids which may play a role as reducing agent. Similar results were observed by various researchers who also synthesized AgNPs using different plant extracts [28-30].

\section{UV-Visible spectrophotometric analysis of AgNPs}

The silver ion reduction to a silver atom in the test solution was observed using the UV-Visible spectrophotometer. The change in colour was observed due to the reduction of Ag+leading to the formation of AgNPs. The colour change is primarily due to excitation of surface Plasmon vibrations which is a characteristic observation during the formation of AgNPs. In the present study, maximum absorption peaks were recorded and found to be $425 \mathrm{~nm}$ after $24 \mathrm{~h}$ which further confirmed the formation of AgNPs (fig. 2). The synthesized AgNPs absorbs radiation strongly at characteristic wavelengths due to its electrons transition. The exact mechanism of metal nanoparticles synthesis is not well understood. However reports suggest that the reduction was due to the role of NADH coenzyme in the medium $[31,32]$. 


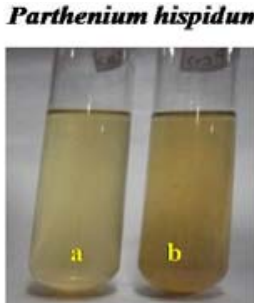

Phyllanthus amarus

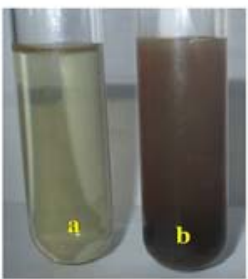

Tectona grandis
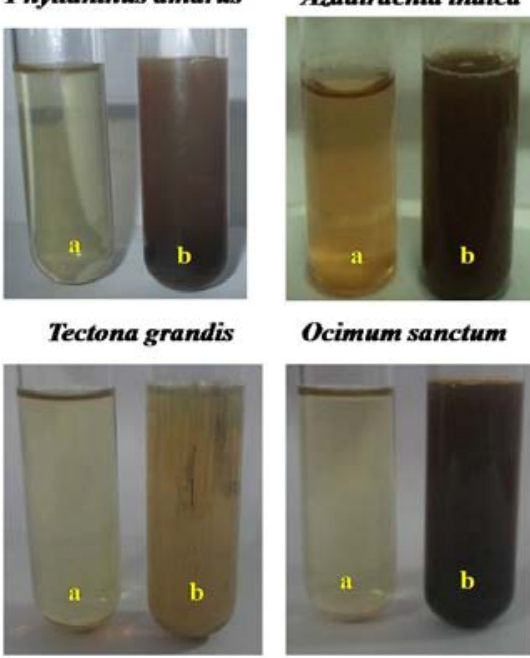

Ocimum sanctum
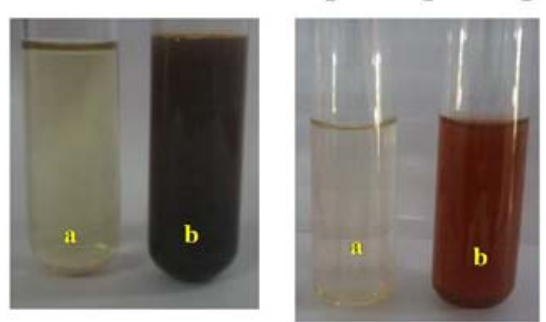

Fig. 1: Screening of AgNPs synthesis using different plant extracts

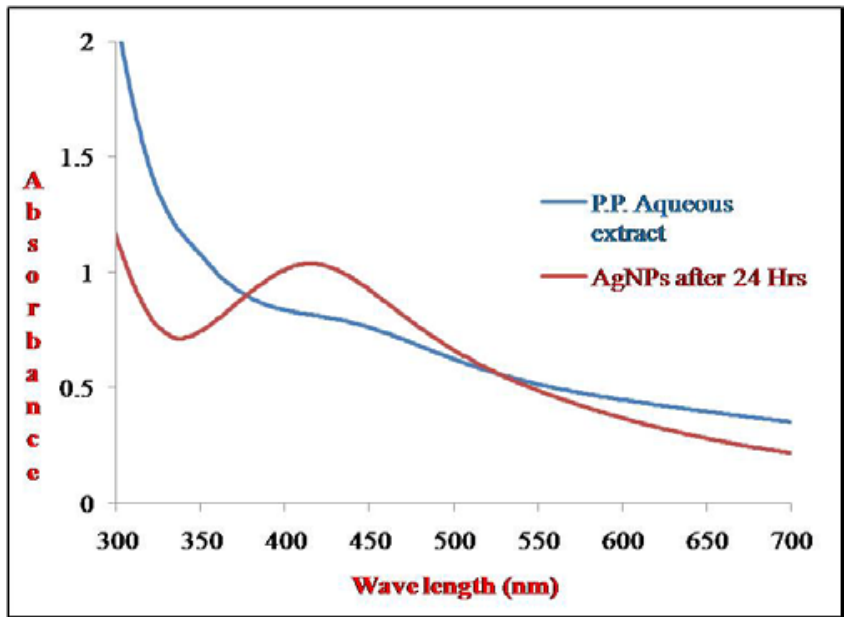

Fig. 2: UV-Visible spectrophotometric analysis of synthesized AgNPs

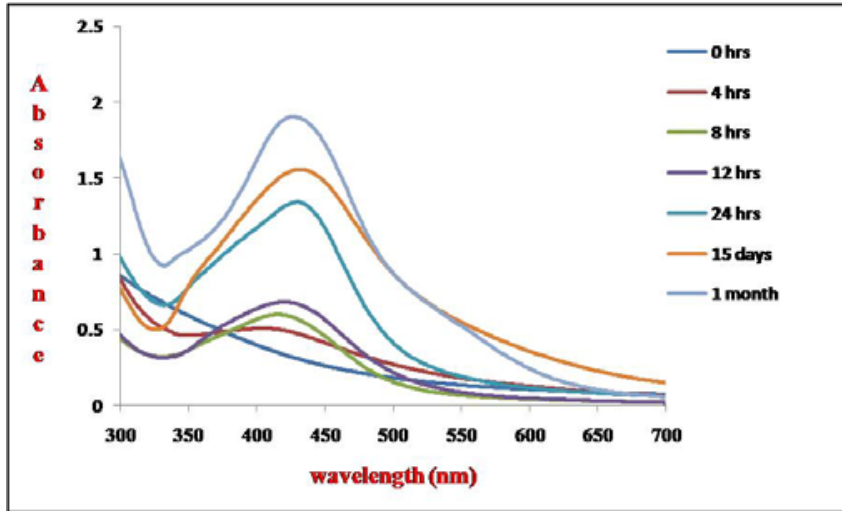

Fig. 3: Stability studies of synthesized AgNPs 


\section{Stability studies of phytosynthesized AgNPs}

The Peltophorum pterocarpum leaves extract mediated AgNPs was analyzed for their stability studies using UV-Visible spectroscopy. The maximum spectra of synthesized AgNPs were monitored using UV-Visible spectrophotometer from $0 \mathrm{~h}$ to $1 \mathrm{mo}$. Initially, at $4 \mathrm{~h}$, a maximum spectrum was recorded at $380 \mathrm{~nm}$ which confirmed the formation of AgNPs, further there is an increase in peak from 380 $\mathrm{nm}$ to $420 \mathrm{~nm}$ at the end of $12 \mathrm{~h}$. The results reveal the maximum absorption spectra of synthesized AGNPs was found to be $425 \mathrm{~nm}$ even after $1 \mathrm{mo}$, which confirms the potential stability of AgNPs synthesized using P. pterocarpum (fig. 3 ). The above results conclude that the silver nanoparticle activity was started at $8 \mathrm{~h}$ and it was ended at $24 \mathrm{~h}$ and after that its activity was stable up to a month.

\section{XRD analysis of AgNPs}

The XRD spectra of the synthesized AgNPs showed three distinct peaks representing Bragg reflections of 111,200 , and 220 which corresponds to the face-centered cubic (fcc) of the silver confirming the crystalline nature of the photosynthesized AgNPs. The spectral data obtained were well matched with previously reported literature which also shows similar results [33, 34].

\section{FTIR analysis of leaf extract and AgNPs}

Results of the FTIR spectrum of both the leaf extract and AgNPs synthesized were shown in fig. 4. The spectrum of Peltophorum pterocarpum leaf extracts and synthesized AgNPs shows several absorption peaks at 3250,1614, 1535, 1333, 963 and $883 \mathrm{~cm}^{-1}$. The intense absorption peaks of $3250 \mathrm{~cm}^{-1}$ represent the hydroxyl groups of plant components such as alcohols and phenolic compounds. An absorption peak of 1614 indicates $\mathrm{C}=\mathrm{O}$ amide stretch due to the presence of proteins which were similar to the observation reported by Ahmad and co-workers [35]. Less intense peak at $1333 \mathrm{~cm}^{-1}$ denotes the-C-N stretching vibrations due to the aromatic amines present in both the spectra of synthesized AgNPs and leaf extracts $[2,36,37]$. The results of both FTIR spectra clearly reveals that the dual role of leaf components which acted as both reducing and capping agents during the synthesis of AgNPs which was observed well in the presence of various corresponding peaks.

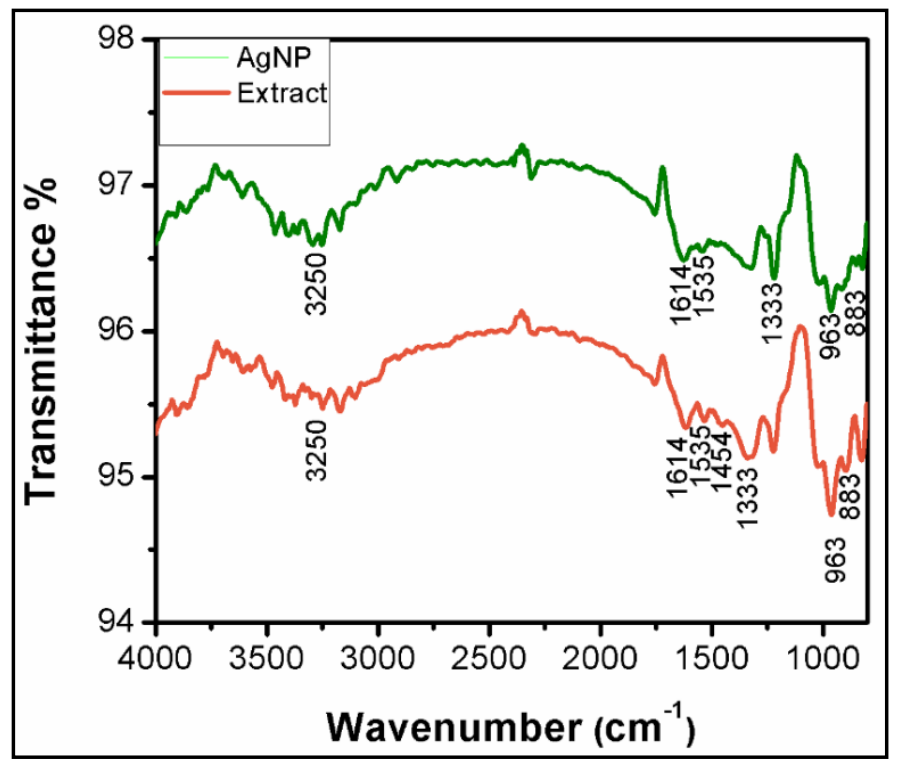

Fig. 4: FTIR analyses of leaf extract and synthesized AgNPs

\section{TEM analysis of AgNPs}

The TEM analysis was used to determine the size and shape of the AgNPs. The TEM results of the present study revealed that the nanoparticles synthesized were of spherical shape with an average size ranging from 20 to $60 \mathrm{~nm}$ distributed evenly (fig. 5a) and the inset (fig. 5b) shows SAED pattern. The EDX spectrum also revealed the presence of silver peaks which confirms the synthesis of AgNPs (fig. 6). Gavade and co-workers developed a single step biogenic method for the synthesis of AgNPs using leaf extract of Ziziphus jujube. They also measured the size of AgNPs using TEM analysis, averaging about $25 \mathrm{~nm}$ [38]. Several researchers also studied the morphology and size of AgNPs synthesized from different plant extracts using TEM analysis also reveals the presence of monodisperse spherical nanoparticles ranging between $2060 \mathrm{~nm}$ $[39,40]$.

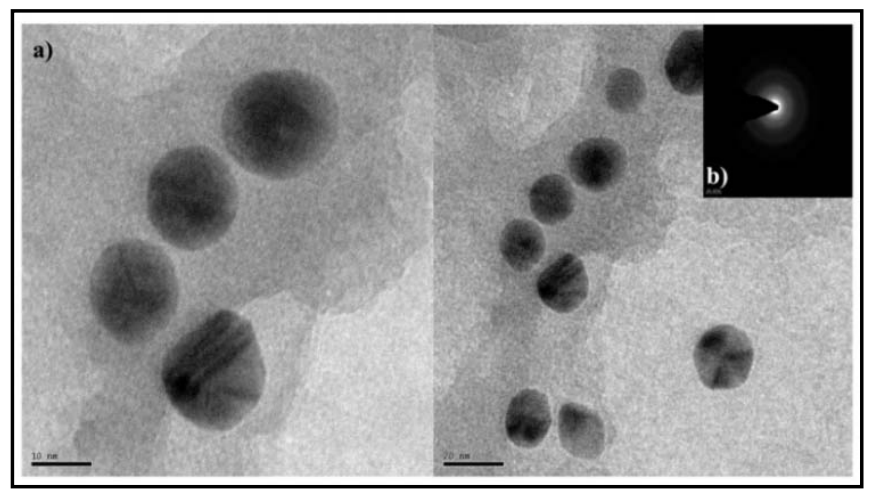

Fig. 5a and $b$ : TEM and SAED analysis of synthesized AgNPs 


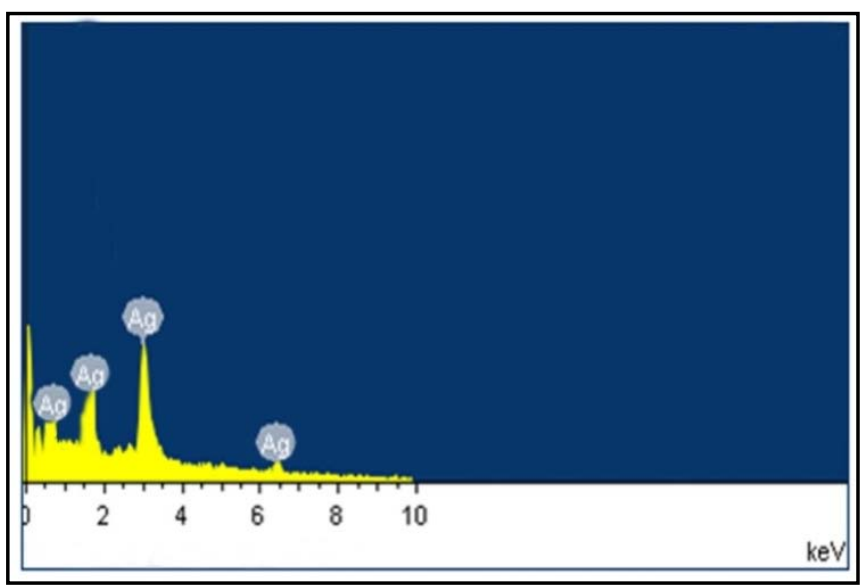

Fig. 6: EDX analysis of synthesized AgNPs

\section{Antibacterial studies of phytosynthesized AgNPs}

In the present study, AgNPs synthesized using Peltophorum pterocarpum leaves extract was tested for their efficacy against four different bacterial pathogens, namely Staphylococcus aureus, Bacillus subtilis, Escherichia coli and Pseudomonas aeruginosa at four different concentrations. Among the tested strains, in general, AgNPs shows good inhibition activity against Gram-negative bacteria compared to
Gram-positive bacteria. Maximum inhibition activity was found when AgNPs $(100 \mu \mathrm{g} / \mathrm{ml})$ was treated against P. aeruginosa which recorded a zone of inhibition of $16 \mathrm{~mm}$ (table 1). This followed by AgNPs treated B. subtilis showed a zone of inhibition of $18 \mathrm{~mm}$ when tested at 100 $\mu \mathrm{g} / \mathrm{ml}$ (fig. 7). This present study also shows that the antibacterial activity was concentration dependent as the concentration of AgNPs increases the antibacterial activity. Standard positive control was tested for antibacterial activity against all the tested strains.

Table 1: Antibacterial Activity of AgNPs using well diffusion method

\begin{tabular}{|c|c|c|c|c|c|}
\hline \multirow[t]{2}{*}{ Test bacterial pathogens } & \multicolumn{5}{|c|}{ Zone of inhibition (mm)* } \\
\hline & $\begin{array}{l}\text { AgNPs } \\
25 \mu \mathrm{g} / \mathrm{ml}\end{array}$ & $\begin{array}{l}\text { AgNPs } \\
50 \mu \mathrm{g} / \mathrm{ml}\end{array}$ & $\begin{array}{l}\text { AgNPs } \\
75 \mu \mathrm{g} / \mathrm{ml}\end{array}$ & $\begin{array}{l}\text { AgNPs } \\
100 \mu \mathrm{g} / \mathrm{ml}\end{array}$ & $\begin{array}{l}\text { Gentamicin } \\
10 \mu \mathrm{g} / \mathrm{ml}\end{array}$ \\
\hline Staphylococcus aureus & $12.12 \pm 0.14$ & $12.07 \pm 0.52$ & $14.07 \pm 0.22$ & $15.18 \pm 0.43$ & $18.07 \pm 0.24$ \\
\hline Bacillus subtilis & $14.59 \pm 0.23$ & $15.67 \pm 0.75$ & $16.04 \pm 0.38$ & $18.04 \pm 0.74$ & $20.04 \pm 0.40$ \\
\hline Escherichia coli & $8.16 \pm 0.37$ & $8.35 \pm 0.98$ & $10.25 \pm 0.55$ & $12.08 \pm 1.09$ & $15.51 \pm 0.59$ \\
\hline Pseudomonas aeruginosa & $12.15 \pm 0.52$ & $12.80 \pm 1.21$ & $14.25 \pm 0.73$ & $16.49 \pm 1.47$ & $14.27 \pm 0.78$ \\
\hline
\end{tabular}

*All the experiments were repeated independently three times. Values were represented as an average means \pm standard deviation.

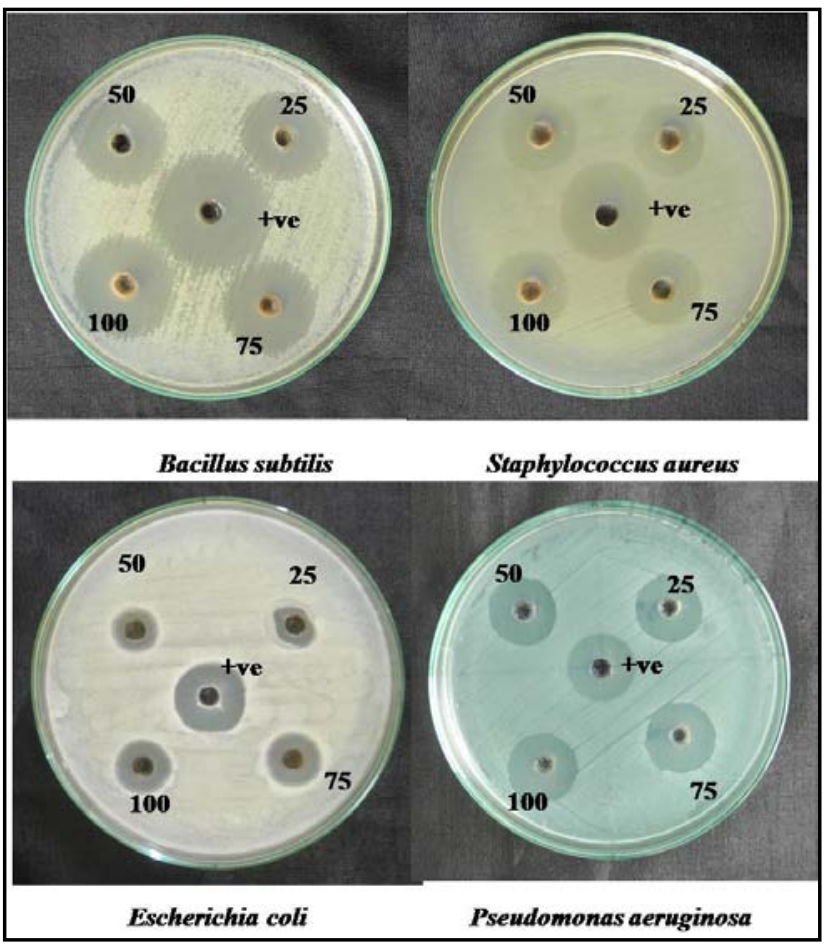

Fig. 7: Antibacterial activity of AgNPs using well diffusion method 
Though the antibacterial effect of AgNPs was well studied, the mechanism of antimicrobial action was still unclear. Few reports suggested that the size of nanoparticles plays a major role in the antibacterial property against pathogens. Earlier studies also show that the antibacterial property may be due to electrostatic interaction, increased permeability and influence on membrane transport [41-44]. Several researchers have investigated the antibacterial property of AgNPs against human pathogens using the well diffusion method. The findings of our study were well supported by researchers who have tested the antibacterial activity of AgNPs against human pathogens [25, 45, 46].

\section{Antifungal studies of phytosynthesized AgNPs}

The antifungal activity of AgNPs against A. niger was studied using the agar well diffusion method. The maximum zone of inhibition $(12$ $\mathrm{mm}$ ) was found when AgNPs was tested with $100 \mu \mathrm{g} / \mathrm{ml}$ of concentration against $A$. niger. The positive control amphotericin $\mathrm{B}$ was tested against $A$. niger, and the zone of inhibition was found to be $18 \mathrm{~mm}$ (fig. 8). The mechanism of antifungal action of AgNPs was still not clear. Similar studies were performed by Bahrami-Teimoori and their co-workers (2017) who have reported the antifungal property of AgNPs against Macrophomina phaseolina, Fusarium oxysporum and Alternaria alternate [47]. Similar studies were also reported by earlier researchers who investigated the antifungal activity against human fungal pathogens $[23,48]$.

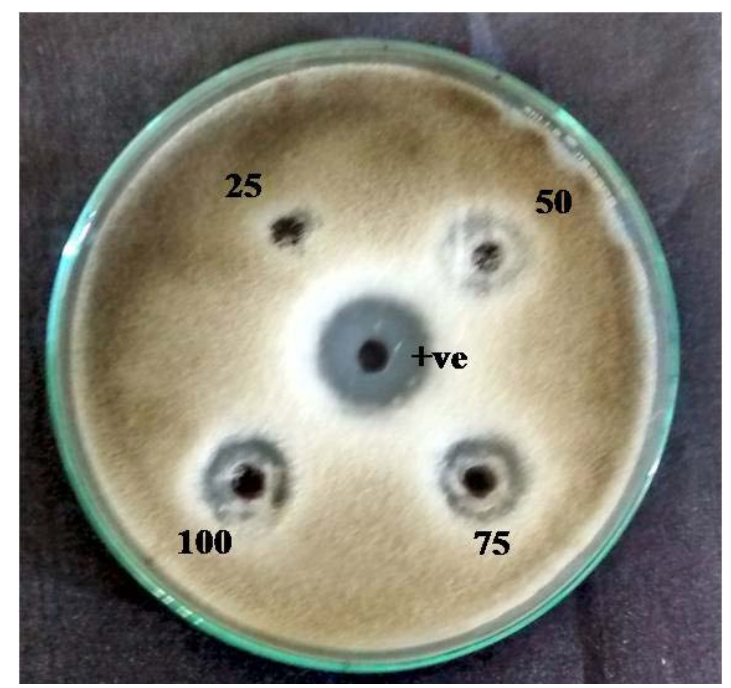

Fig. 8: Antifungal activity of AgNPs using well diffusion method

\section{CONCLUSION}

In the present study, five different plants were studied for the synthesis of AgNPs. Among the five plants, the AgNPs synthesized using Peltophorum pterocarpum leaves extract shows good stability, which was further characterized and tested for their antimicrobial property. The synthesized AgNPs was found to be spherical and had potent antimicrobial activity against both bacterial and fungal pathogens. The synthesized AgNPs showed a broad spectrum of antibacterial activity against both the Gram-positive and Gramnegative bacteria. Maximum activity AgNPs was found against $P$. aeruginosa followed by B. subtilis. The AgNPs also showed potent activity against filamentous fungi, A. niger which clearly confirms that the synthesized AgNPs could be a potent antimicrobial agent. However, a further detailed study is required to reveal the exact mechanism and role of AgNPs against the human pathogens.

\section{ACKNOWLEDGMENT}

The authors need to the Director, CAS in Botany, University of Madras, Chennai, for providing the laboratory facilities. We thank NCNSNT, University of Madras, for providing characterization studies.

\section{AUTHORS CONTRIBUTIONS}

All the author have contributed equally

\section{CONFLICTS OF INTERESTS}

Authors declare no conflicts of interest

\section{REFERENCES}

1. Baharara J, Namvar F, Ramezani T, Mousavi M, Mohamad R. Silver nanoparticles biosynthesized using Achillea biebersteinii flower extract: apoptosis induction in MCF-7 cells via caspase activation and regulation of $\mathrm{Bax}$ and $\mathrm{Bcl}-2$ gene expression. Molecules 2015;20:2693-706.

2. Salehi S, Shandiz SA, Ghanbar F, Darvish MR, Ardestani MS, Mirzaie A, et al. Phytosynthesis of silver nanoparticles using Artemisia marschalliana sprengel aerial part extract and assessment of their antioxidant, anticancer, and antibacterial properties. Int J Nanomed 2016;11:1835-46.

3. Sharma VK, Yngard RA, Lin Y. Silver nanoparticles: green synthesis and their antimicrobial activities. Adv Colloid Interface Sci 2009;145:83-96.

4. $\mathrm{Xu} \mathrm{ZP,} \mathrm{Zeng} \mathrm{QH}, \mathrm{Lu} \mathrm{GQ}, \mathrm{Yu} \mathrm{AB}$. Inorganic nanoparticles as carriers for efficient cellular delivery. Chem Eng Sci 2006;61:1027-40.

5. Anbarasu A, Karnan P, Deepa N, Usha R. Carica papaya mediated green synthesized silver nanoparticles. Int J Curr Pharm Res 2018;10:15-20.

6. Grover A, Yadav S, Vats V. Medicinal plants of India with antidiabetic potential. J Ethnopharmacol 2002;81:81-100.

7. Ayyanar BM, Ignacimuthu S. Ethnobotanical survey of medicinal plants commonly used by Kani tribals in Tirunelveli hills of Western Ghats. India J Ethnopharmacol 2011;134 :851-64.

8. Sahadevan R. Green synthesis and characterization of the silver nanoparticle using leaf extract of Capparis zeylanica. Asian J Pharm Clin Res 2014;7:44-8.

9. Lotha R, Sivasubramanian A, Muthuraman MS. Silver nanoparticles from medicinally important Euphorbia cyathophora extract: biosynthesis, characterization, and anticancer activity. Asian J Pharm Clin Res 2018;11:154-6.

10. Khan M, Khan ST, Khan M. Antibacterial properties of silver nanoparticles synthesized using Pulicaria glutinosa plant extract as a green bioreduction. Int J Nanomed 2014;9:3551-65.

11. Salunke GR, Ghosh S, Kumar RJS. Rapid, efficient synthesis and characterization of silver, gold, and bimetallic nanoparticles from the medicinal plant Plumbago zeylanica and their application in biofilm control. Int J Nanomed 2014;9:2635-53.

12. Govender R, Phulukdaree A, Gengan RM, Anand K, Chuturgoon AA. Silver nanoparticles of Albizia adianthifolia: the induction of apoptosis in human lung carcinoma cell line. J Nanobiotechnol 2013;11:5

13. Sankar R, Karthik A, Prabu A, Karthik S, Shivashankari KS, Ravikumar V. Origanum vulgare mediated biosynthesis of silver nanoparticles for its antibacterial and anticancer activity. Colloids Surf B 2013;108:80-4.

14. Vivek R, Thangam R, Muthuchelian K, Gunasekaran P, Kaveri K, Kannan S. Green biosynthesis of silver nanoparticles from Annona squamosa leaf extract and it's in vitro cytotoxic effect on MCF-7 cells. Process Biochem 2012;47:2405-10.

15. Kalainila P, Subha V, Ernest Ravindran RS, Sahadevan R. Synthesis and characterization of silver nanoparticles from Erythrina indica. Asian J Pharm Clin Res 2014;7:39-43.

16. Kapil A. The challenge of antibiotic resistance: need to contemplate. Indian J Med Res 2005;121:83-91.

17. Morones JR, Elechiguerra JL, Camacho A, Holt K, Kouri JB, Ramírez JT, Yacaman MJ. The bactericidal effect of silver nanoparticles. Nanotechnology 2005;16:2346-53.

18. Rai M, Yadav A, Gade A. Silver nanoparticles as a new generation of antimicrobials. Biotechnol Adv 2009;27:76-83.

19. Ankanna S, Savithramma N. Biological synthesis of silver nanoparticles by using the stem of Shorea tumbuggaia Roxb. and its antimicrobial efficacy. Asian J Pharm Clin Res 2011;4:137-41.

20. Kim JS, Kuk E, Yu KN, Kim JH, Park SJ, Lee HJ, et al. Antimicrobial effects of silver nanoparticles. Nanomed Nanotechnol 2007;3:95-101. 
21. Chen X, Schluesener HJ. Nanosilver: a nanoproduct in medical application. Toxicol Appl Pharmacol Lett 2008;176:1-12.

22. Balashanmugam $\mathrm{P}$, Balakumaran MD, Murugan R, Dhanapal $\mathrm{K}$ Kalaichelvan PT. Phytogenic synthesis of silver nanoparticles, optimization, and evaluation of in vitro antifungal activity against human and plant pathogens. Microbiol Res 2016; 192:52-64.

23. Singh K, Panghal M, Kadyan S, Chaudhary U, Yadav JP. Green silver nanoparticles of Phyllanthus amarus: as an antibacterial agent against multi-drug resistant clinical isolates of Pseudomonas aeruginosa. J Nanobiotechnol 2014;12:40.

24. Składanowski M, Golinska P, Rudnicka K, Dahm H, Rai M. Evaluation of cytotoxicity, immune compatibility and antibacterial activity of biogenic silver nanoparticles. Med Microbiol Immunol 2016;205:603-13.

25. Saravanan M, Venu AK, Barik SK. Rapid biosynthesis of silver nanoparticles from Bacillus megaterium (NCIM 2326) and their antibacterial activity on multi-drug resistant clinical pathogens. Colloids Surf B 2011;88:325-31.

26. Rana IS, Rana AS, Rajak RC. Evaluation of antifungal activity in the essential oil of the Syzygium aromaticum (L.) by extraction, purification, and analysis of its main component eugenol. Braz J Microbiol 2011;42:1269-77.

27. Okafor F, Janen A, Kukhtareva T, Edwards V, Curley M. Green synthesis of silver nanoparticles, their characterization, application, and antibacterial activity. Int J Environ Res Public Health 2013;10:5221-38.

28. Kumar R, Ghoshal G, Jain A, Goyal M. Rapid green synthesis of silver nanoparticles (AgNPs) using (Prunus persica) plants extract: exploring its antimicrobial and catalytic activities. J Nanomed Nanotechnol 2017;8:1-8.

29. Niraimathi KL, Sudha V, Lavanya R, Brindha P. Biosynthesis of silver nanoparticles using Alternanthera sessilis (Linn.) extract and their antimicrobial, antioxidant activities. Colloids Surf B 2013;102:288-91.

30. Oluwaniyi 00, Adegoke HI, Adesuji ET, Alabi AB, Bodede SO. Biosynthesis of silver nanoparticles using aqueous leaf extract of Thevetia peruviana Juss. and it's antimicrobial activities. Appl Nanosci 2015;6:903-12.

31. Labrenz M, Druschel GK, Thomsen-Ebert T, Gilbert B, Welch SA, Kemner KM, et al. Formation of sphalerite $(\mathrm{ZnS})$ deposits in natural biofilms of sulfate-reducing bacteria. Science 2000; 290:1744-7.

32. Roh Y, Lauf RJ, McMillan AD, Zhang C, Rawn CJ, Bai J, et al. Microbial synthesis and the characterization of metalsubstituted magnetites. Solid State Commun 2001;118:529-34.

33. Premasudha $P$, Venkataramana M, Abirami M, Vanathi $P$, Krishna K, Rajendran R. Biological synthesis and characterization of silver nanoparticles using Eclipta alba leaf extract and evaluation of its cytotoxic and antimicrobial potential. Bull Mater Sci 2015;38:965-73.
34. Shankar SS, Ahmad A, Sastry M. Geranium leaf assisted biosynthesis of silver nanoparticles. Biotechnol Prog 2003; 19:1627-31.

35. Ahmad N, Bhatnagar S, Ali SS, Dutta R. Phytofabrication of bioinduced silver nanoparticles for biomedical applications. Int J Nanomed 2015;10:7019-30.

36. Ibrahim M, Alaam M, El-Haes H, Jalbout AF, Leon AD. Analysis of the structure and vibrational spectra of glucose and fructose. Ecletica Quim 2006;31:15-21.

37. Veerasamy R, Xin TZ, Gunasagaran S, Xiang TFW, Yang EFC, Jeyakumar N. Biosynthesis of silver nanoparticles using mangosteen leaf extract and evaluation of their antimicrobial activities. J Saudi Chem Soc 2011;15:113-20.

38. Gavade NL, Kadam AN, Suwarnkar MB, Ghodake VP, Garadkar KM. Biogenic synthesis of multi-applicative silver nanoparticles by using Ziziphus Jujuba leaf extract. Spectrochim Acta A Mol Biomol Spectrosc 2015;136:953-60.

39. Edison TJI, Sethuraman MG. Instant green synthesis of silver nanoparticles using Terminalia chebula fruit extract and evaluation of their catalytic activity on the reduction of methylene blue. Pro Biochem 2012;47:1351-7.

40. Zargar M, Shameli K, Najafi GR, Farahani F. Plant-mediated green biosynthesis of silver nanoparticles using Vitex negundo L extract. J Ind Eng Chem 2014;20:4169-75.

41. Vanaja M, Annadurai G. Coleus aromaticus leaf extract mediated synthesis of silver nanoparticles and its bactericidal activity. Appl Nanosci 2013;3:217-23.

42. Lara HH, Garza Trevino EN, Ixtepan Turrent L, Singh DK. Silver nanoparticles are broad-spectrum bactericidal and virucidal compounds. J Nanobiotechnol 2011;9:30.

43. Kim SH, Lee HS, Ryu DS, Choi SJ, Lee DS. Antibacterial activity of silver-nanoparticles against Staphylococcus aureus and Escherichia coli. Korean J Microbiol Biotechnol 2011;39:77-85.

44. Sondi I, Salopek Sondi B. Silver nanoparticles as antimicrobial agent: a case study on E. coli as a model for gram-negative bacteria. J Colloid Interface Sci 2004;275:177-82.

45. Renugadevi K, Aswini RV. Microwave irradiation assisted synthesis of the silver nanoparticle using Azadirachta indica leaf extract as a reducing agent and in vitro evaluation of its antibacterial and anticancer activity. Int J Nanomat Bio 2012;2:5-10.

46. Sadhasivam S, Shanmugam P, Yun K. Biosynthesis of silver nanoparticles by Streptomyces hygrocopicus and antimicrobial activity against medically important pathogenic microorganisms. Colloids Surf B 2010;81:358-62.

47. Bahrami Teimoori B, Nikparast Y, Hojatianfar M, Akhlaghi M, Ghorbani R, Pourianfar HR. Characterisation and antifungal activity of silver nanoparticles biologically synthesised by Amaranthus retroflexus leaf extract. J Exp Nanosci 2017;12:129-39.

48. Krishnaraj C, Ramachandran R, Mohan K, Kalaichelvan PT. Optimization for rapid synthesis of silver nanoparticles and its effect on phytopathogenic fungi. Spectrochim Acta A Mol Biomol Spectrosc 2012;93:95-9. 